\title{
EL VELO: CUESTIÓN DE SEMIOLOGÍA
}

Laredj Kandouci

À ma grande petite sœur Mina

En esta cuestión de semiología, tan breve, planteamos la pregunta siguiente: ¿por qué nos vestimos? Trataremos algunas nociones teóricas, la doble función del vestido, y como ejemplo concreto, el velo, largo, hasta los pies, que llevan las mujeres en los países norteafricanos.

La comunicación humana no se agota únicamente a través del habla, en el dominio verbal puro. Existen otros medios de comunicación. Hablar es el modo de comunicar una aptitud, interpretar y transmitir mensajes; ¿pero es únicamente el habla lo que asegura el intercambio, la circulación de significados?

En efecto, la comunicación humana no se confina a lo verbal: miradas, gestos, comportamientos, vestidos, entornos espacio-temporales, dibujos... ofrecen suficientes elementos para que se establezca cierta comprensión mutua.

Intentaremos analizar esto modestamente a través del vestido, para incidir en que existe comunicación de manera muy expresiva sin necesidad de palabras. Otorgar tal importancia al vestido no es algo nuevo. Es una preocupación que juzgamos universal, se remonta al origen de los tiempos.

Según la leyenda, el hombre empezó cubriéndose con hojas de parra. Esta forma de vestido ha evolucionado con el tiempo. Desde las pieles del hombre de la caverna, hasta hoy en día con variedad de prendas sintéticas a merced de la moda. Además, podemos añadir que al nacer el hombre está desnudo: hay que cubrirlo. ¿No es ésta la primera función del vestido, la de proteger?

Este fenómeno humano ha llegado a ser tan inconsciente en nuestros días que no se le da importancia alguna en la medida en que se le atribuyen otras funciones: la comunicación y la significación. La primera va siempre acompañada de la segunda. Esto nos lleva a preguntarnos sobre estas dos nociones y a definirlas. Dalila Morsli en su obra Introducción 
a la semiología, Argel, SNED, I983, hace una síntesis de dos escuelas antagónicas, una representada por Prieto, Buyssens, Martinet y Mounin que preconiza una semiología de la comunicación, y la otra dirigida por Barthes, que estipula una semiología de la significación. Nos da la definición siguiente: "la semiología de la comunicación se puede definir como el estudio de procedimientos de comunicación, es decir, de los medios utilizados para ejercer influencia sobre el prójimo reconociéndolos como tales aquél a quien se quiere influenciar".

Para hacer más comprensible esta cita, veamos cómo estos lingüistas definen la comunicación: "el acto de comunicación es el acto por el cual un individuo, conociendo un hecho perceptible, asociado a cierto estado de conciencia, lo realiza para que otro individuo comprenda el objetivo de ese comportamiento y reconstruya en su propia conciencia lo que ocurre en la del primero".

$\mathrm{Al}$ contrario, la semiología de la significación, según Barthes, plantea el problema de forma diferente. Para él, el acto de comunicación que establece una relación social es algo perfectamente transparente y armonioso. Según su teoría, podemos distinguir siempre dos sentidos, uno denotado y el otro connotado. Así se destaca el "estar metido en el proceso de comunicación". Es cierto que hay siempre algo présupposé en nuestros vestidos sin tener conciencia.

Con todo, podemos resumir las nociones adelantadas a través de un esquema que proponemos:

\section{¿COMUNICACIÓN O SIGNIFICACIÓN? \\ Un sistema de signos}

Para Mounin:

-Se define por su función
Para Barthes:

-Tiene una o más significaciones

-Sirve para la comunicación humana

Consideremos la mirada: él ve lo que no se ve, lo escondido. El sujeto de la vida humana está, en efecto, sometido a un bombardeo continuo de mensajes que no manifiestan siempre una intencionalidad directa, pero que tienden frecuentemente, en razón misma de su finalidad ideológica, a presentarse en forma de inocente reciprocidad de lo "real". 
Para el psicoanalista, por ejemplo, el vestido es el objeto de "transferencia", de "sublimación" y de "tendencias exhibicionistas". Los vestidos que llevamos simbolizan las funciones sociales de las que estamos investidos, el papel que jugamos o simplemente valores estéticos ligados a un género particular de vida o a una condición. Estas interacciones comunicativas no verbales son casi sentidas como paliativos. ¿Paliativos de qué? Del habla, puesto que éste: "es fugitivo, entonces no siempre es adecuado cuando se trata de transmitir un mensaje".

En consecuencia, el habla queda relegada e ignorada: "agoniza y se reemplaza por otros signos". El término "signo" pertenece al uso corriente y se designa indiferentemente de las entidades que, en el uso más estricto, reciben definiciones específicas. Según Barthes, el intercambio de signos es de una riqueza, de una movilidad y de una sutilidad fascinantes a pesar de la opacidad de la lengua. Para Mounin: "ver en un objeto un signo, es atribuirle primero significaciones virtuales, luego interpretarlo es, en alguna medida, privilegiar una de sus significaciones en virtud de lo que se conoce ya".

Este conocimiento puede ser el fruto de una experiencia del mundo $\mathrm{y}$ de las cosas. Para el vestido hay una función primera, que no es de orden semiológico, la función protectora (que sería el signo lingüístico). Barthes declara que el vestido de un individuo es un discurso. El ideal de un signo (semiológico) sería entonces que fuera arbitrario para una mejor realización del proceso semiológico.

En el "Sistema de la moda" de Roland Barthes, el signo es arbitrario, cada año el léxico de la moda es nuevo, como el de la lengua, que guardará siempre algo, pero que cambiará brusca y regularmente "la moneda" de esas palabras.

Las conductas cotidianas de lo vivido, nos revela la simbolización del velo largo hasta los pies que llevan las mujeres en el Magreb. Si en otro tiempo el velo era de borradura femenina, hoy día pierde mucho de su impacto en la nueva generación que lo considera como símbolo de la espantada. Así, algunas mujeres jóvenes cuando están en casa de la cartomántica, o cuando se reúnen con su amante, en este momento usan el velo, para que sus encuentros queden en el anonimato. Este hecho está considerado como indicio, puesto que este último es un hecho observable que nos informa sobre otro que no lo es directamente. Pero 
puede ser también una señal de que un hombre reconociera una "mujer de la vida” con su largo velo tapándole la cara y enseñando sin embargo una pierna excitante.

Un código común se establece entre ellos: deseo e intención de comunicar. Ésta sería una utilización interesada, puesto que el velo sería en estos casos una prenda práctica en el momento en que la mujer se encontrara en la obligación de ajustar un precio.

Presuponemos otro caso, la mujer no desea, entonces el velo, es para ocultar una "miseria escondida". Lo que suponíamos se presenta como una evidencia algo irrebatible, algo que se impone tanto al receptor como al emisor, y que aceptarán ellos dos.

Por otra parte, y en el ámbito social de los países beréberes, árabes y musulmanes, el velo largo hasta los pies es una forma de respeto y educación arraigada en las tradiciones, como símbolo de civilización. Así, pues, nos dirigimos hacia lo simbólico cuando se trata de presentar algo de lo que no podríamos dar una representación icónica, como el miedo, la alegría, la guerra, la justicia y la democracia.

\section{LECTURAS:}

Roland Barthes, Système de la mode, París, Édition du Seuil, I972.

Pierre Guirraud, La sémiologie, París, Puf, 1975.

Jeanne Martinet, Clefs pour la sémiologie, París, Édition du Seuil, I972.

George Mounin, Introduction à la sémiologie, París, Édition du Seuil, I973.

Jean Luis Prieto, Méssages et signaux, París, Édition du Seuil, i973. 